University of Montana

ScholarWorks at University of Montana

Numerical Terradynamic Simulation Group

Publications

Numerical Terradynamic Simulation Group

3-1996

\title{
Global vegetation cover changes from coarse resolution satellite data
}

Ramakrishna R. Nemani

Steven W. Running

University of Montana - Missoula

Roger A. Pielke

Thomas N. Chase

Follow this and additional works at: https://scholarworks.umt.edu/ntsg_pubs Let us know how access to this document benefits you.

\section{Recommended Citation}

Nemani, R. R., S. W. Running, R. A. Pielke, and T. N. Chase (1996), Global vegetation cover changes from coarse resolution satellite data, J. Geophys. Res., 101(D3), 7157-7162, doi:10.1029/95JD02138

This Article is brought to you for free and open access by the Numerical Terradynamic Simulation Group at ScholarWorks at University of Montana. It has been accepted for inclusion in Numerical Terradynamic Simulation Group Publications by an authorized administrator of ScholarWorks at University of Montana. For more information, please contact scholarworks@mso.umt.edu. 


\title{
Global vegetation cover changes from coarse resolution satellite data
}

\author{
Ramakrishna R. Nemani and Steven W. Running \\ School of Forestry, University of Montana, Missoula \\ Roger A. Pielke and Thomas N. Chase \\ Department of Atmospheric Science, Colorado State University, Fort Collins
}

\begin{abstract}
Land cover plays a key role in various biophysical processes related to global climate and terrestrial biogeochemistry. Although global land cover has dramatically changed over the last few centuries, until now there has been no consistent way of quantifying the changes globally. In this study we used long-term climate and soils data along with coarse resolution satellite observations to quantify the magnitude and spatial extent of large-scale land cover changes attributable to anthropogenic processes.

Differences between potential leaf area index (LAI), derived from climate-soil-leaf area equilibrium, and actual leaf area index obtained from satellite data are used to estimate changes in land cover. Further, changes in LAI between potential and actual conditions are linked to climate by expressing them as possible changes in radiometric surface temperatures $\left(T_{\mathrm{r}}\right)$ resulting from changes in surface energy partitioning. As expected, areas with high population densities, such as India, China, and western Europe showed large reductions in LAI. Changes in global land cover expressed as summer, midafternoon $T_{\mathrm{r}}$, ranged from $-8^{\circ}$ to $+16^{\circ} \mathrm{C}$. Deforestation resulted in an increase in $T_{\mathrm{r}}$, while irrigated agriculture reduced the $T_{\mathrm{r}}$. Many of the current general circulation models (GCMs) use potential vegetation maps to represent global vegetation. Our results indicate that there are widespread changes in global land cover due to deforestation and agriculture below the resolution of many GCMs, and these changes could have a significant impact on climate. Potential and actual LAI data sets are available for climate modelers at $0.5^{\circ} \times 0.5^{\circ}$ resolution to study the possible impacts of land cover changes on global temperatures and circulation patterns.
\end{abstract}

\section{Introduction}

Previous studies have demonstrated that changes in land cover could be as important as the increase in atmospheric greenhouse gases in climate change [Bonan et al., 1992; Shukla et al., 1990]. For example, deforestation has been found to increase land surface temperatures $\left(T_{\mathrm{s}}\right)$ and reduce rainfall, suggesting a warmer and drier climate [Dickinson and Henderson-Sellers, 1988; Lean and Warilow, 1989; Shukla et al., 1990]. Although it is clear that global land cover has been dramatically altered by human habitation, forest clearing, and agriculture, until now there has been no means of quantifying these changes giobally.

Quantitative analysis of the incredible diversity in global vegetation (species, growth habits, and life forms) is a difficult problem [Running et al., 1994a]. Many classification efforts have been attempted, and their results show wide variations in current estimates of global land cover [Townshend et al., 1991]. A detailed discussion of various land cover classification schemes and their problems is given by Townshend et al. [1991] and Running et al. [1994a]. The consensus from the above studies is that in the advent of rapid anthropogenic changes, only remote sensing data can provide accurate and repeatable means of land cover analysis and monitoring.
Remotely sensed data have been successfully used to study land cover changes at fine to coarse spatial scales. For example, Thematic Mapper data at $30-\mathrm{m}$ resolution were used in the estimation of urban expansion [Haack et al., 1987] and deforestation [Green and Sussman, 1990; Skole and Tucker, 1993]. On the other hand, advanced very high resolution radiometer (AVHRR) data at 1 - and $16-\mathrm{km}$ resolutions were used to estimate land cover at continental scales [Malingreau and Tucker, 1988; Tucker et al., 1985; Turner et al., 1993; Houghton et al., 1993]. At present, all the global satellite databases are derived from the coarse-resolution AVHRR, therefore useful only to study large-scale changes in land cover [Townshend et al., 1991; Goward et al., 1993]. Earlier studies used satellite data primarily for land cover classification. However, recent work has shown that satellite data could be used to quantify biophysical variables such as leaf area index (LAI), canopy cover and fraction of Absorbed Photosynthetically Active Radiation [Nemani and Running, 1989; Pierce et al., 1993; Sellers et al., 1994; Asrar et al., 1992].

Land cover is usually quantified by some measure of plant density. LAI, area of leaves per unit ground area, provides a simple measure of plant canopy density. LAI varies from less than 1 in deserts to greater than 10 over tropical rain forests; therefore changes in LAI can also be indicative of land cover 
between climate- and soil-defined vegetation (potential) and actual vegetation. By using a biophysical variable (LAI), we assumed the influence of the inconsistencies in current vegetation classification schemes could be minimized.

The purpose of this paper is to present a quantitative analysis of the spatial distribution of global land cover changes. Our focus is on anthropogenic changes in land cover, which have occurred over extensive areas, between potential (natural conditions) and present vegetation.

\section{Methods}

To allow for global comparability, we define land cover changes only in terms of differences in maximum LAI. We believe the differences in seasonal maximum LAI are strong indicators of a land cover change and provide a much needed starting point for global land cover change analysis. Maximum LAI under potential and actual conditions for each $0.5^{\circ} \times 0.5^{\circ}$ latitude/longitude grid cell was estimated as follows.

\section{Potential LAI}

To represent vegetation that would have existed before large-scale human influences began, we used a potential biome map, which uses biogeographic principles associating vegetation with long-term climate [Leemans and Cramer, 1990] and soil characteristics [Zobler, 1986], produced at $0.5^{\circ} \times 0.5^{\circ}$ resolution. This geographic biome distribution is based on specific physiological responses of different plant types to cold tolerance, growing season heat sums, and drought stress [Prentice et al., 1992]. Using the same climate and soils data, we also computed geographic variations in potential maximum LAI based on well-established principles of climate-soil-leaf area hydrologic equilibrium [Eagleson, 1982; Nielson, 1995; Woodward, 1987; Nemani and Running, 1989]. The hydrologic equilibrium theory (HET) suggests that plants adjust their leaf area to optimize the use of climate and soil resources. For example, areas with longer growing seasons of optimum temperature and water balance conditions support higher leaf area. This definition of vegetation does not account for natural disturbances such as fire, insects and diseases, and wind extremes on biome distribution.

We used BIOME-BGC, an ecosystem simulation model, to exploit the HET and estimate potential all-sided LAI for each $0.5^{\circ} \times 0.5^{\circ}$ grid cell [Running and Hunt, 1991]. The model uses climate (solar radiation, humidity, air temperature, and rainfall), soil (texture and depth), and vegetation (biome, LAI) information to compute carbon (photosynthesis and respiration) and hydrologic budgets (interception, evaporation, transpiration, and outflow). Snowpack dynamics are simulated using air temperatures and rainfall. Vegetation, taken from potential biome map, is represented only as broadleaf, needle leaf, and grass.

For each grid cell the model starts with an absolute maximum LAI value of 10 [Nielson, 1995]. Stand LAIs greater than 10 are found in nature (10-15 [Gholz, 1982]), however, as an average grid cell value we chose 10 as the upper limit. Then, through an iterative process canopy, LAI is optimized until the peak canopy water stress is below critical level (predawn leaf water potential less than $-2.0 \mathrm{MPa}$ ) and positive carbon bal-
We used the National Oceanic and Atmospheric Administration (NOAA) Global Vegetation Index (GVI) data collected during 1985-1990 mapped to a 10-min grid. These data were calibrated by $\mathrm{K}$. Gallo of NOAA and distributed by the National Geophysical Research Center, Boulder, Colorado. As we are interested in comparing only the maximum LAI that a particular area can achieve under potential versus actual conditions, we first computed a yearly maximum normalized difference vegetation index (NDVI) for the 6 years and then averaged the six maximum values. We assume this 6-year average maximum value to minimize the impact of cloud contamination, atmospheric influence, and interannual variability in climate. Finally, NDVI for each $0.5^{\circ} \times 0.5^{\circ}$ grid cell was produced by taking an average of all the 10 -min grid cells within each $0.5^{\circ} \times 0.5^{\circ}$ area.

To account for the differences in structural and optical properties among different vegetation types, we used separate NDVI-LAI relations for grass (LAI $=$ NDVI $\times 1.71+0.48$ [Asrar et al., 1985]), needle leaf $(\mathrm{LAI}=(\mathrm{NDVI} / 0.31) \hat{0} .26$ [Spanner et al., 1990; Nemani and Running, 1989]) and broadleaf canopies (LAI $=(\mathrm{NDVI} / 0.26) \hat{2}[$ Pierce et al., 1993]). We used Olson et al.'s [1983] vegetation map to represent actual vegetation in terms of grass, needle, and broadleaf canopies. The empirical relations based on field studies were found to corroborate theoretically derived forms of NDVI-LAI relations [Asrar et al., 1992; Sellers et al., 1994]. For example, because of their canopy structure, needle leaf canopies have higher LAI per NDVI than do broadleaf canopies [Sellers et al., 1994]. We acknowledge that the simple empirical relations do not account for problems like variations in background, atmospheric influences, and viewing geometry [Asrar et al., 1992]. However, we believe that using only maximum NDVI values would reduce the impact of many of the above problems.

To quantify the changes in land cover we assumed an accuracy of plus or minus 1 for LAI in both cases [Woodward, 1987; Nemani and Running, 1989; Pierce et al., 1993]. Further we also used a $20 \%$ of maximum LAI ( 5 for grass and shrubs, and 10 for forests) as a threshold for detecting changes. Grid cells with LAI differences less than $20 \%$ maximum for each biome are considered unchanged.

\section{Land Cover Change and Climate}

Radiometric surface temperature measured by orbiting satellite sensors such as AVHRR, though not always coupled to the ambient surface temperature, provide a useful measure of surface energy partitioning [Price, 1984]. Satellite observations show a strong linear relation between LAI and midafternoon surface radiometric temperatures $\left(T_{\mathrm{r}}\right)$, confirming the critical role vegetation plays in regulating surface climate [Nemani et al., 1993; Goward et al., 1985] (Figure 1). Contributions by soil evaporation and transpiration to surface latent heat flux vary with changes in LAI. Under dry soil surface conditions (no soil evaporation), a strong relation is generally observed between LAI and $T_{r}$ over a wide range of vegetation types [Nemani et al., 1993; Goward et al., 1985; Choudhury, 1991; Smith and Choudhury, 1990]. For example, satellite observations over deforested areas of Amazonia, Brazil, clearly show a reduction in LAI and an associated increase in $T_{\mathrm{r}}$ by as much as $14^{\circ} \mathrm{C}$ (Plate 1). Since surface temperature provides a key link between land 


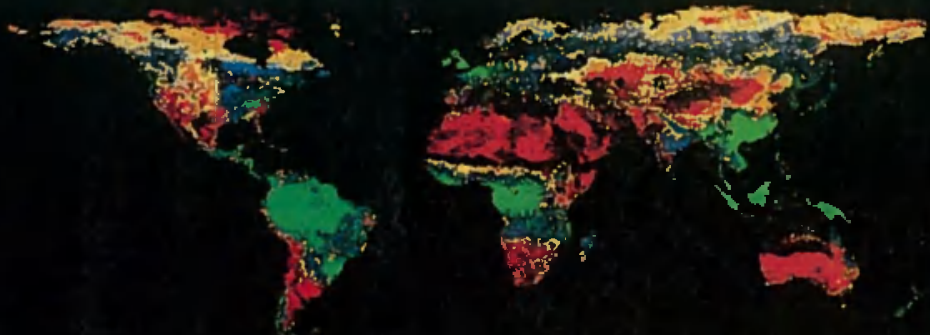

Actual Leaf Area Index derived from satellite data

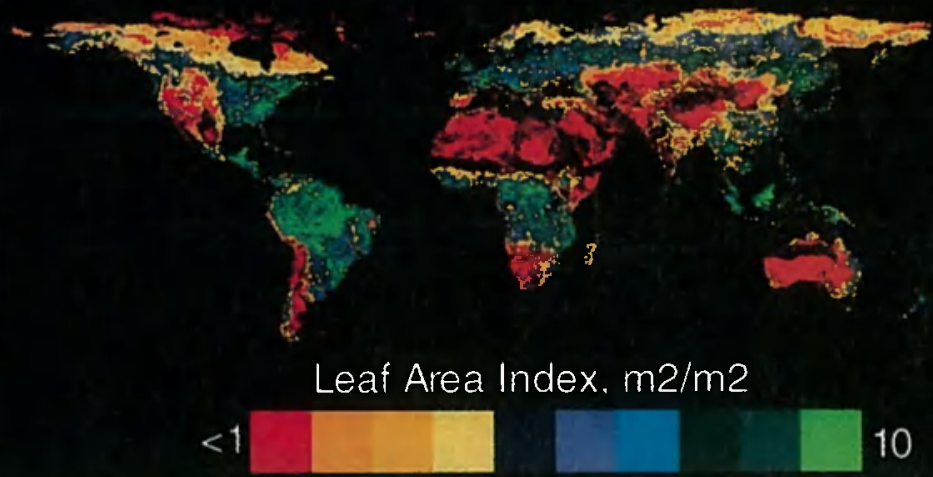

Plate 2. Spatial distributions of potential LAI, derived from climate-soil-leaf area hydrologic equilibrium using long-term climate and soils data, and actual LAI estimated from coarse-resolution NOAA/AVHRR data.

Few areas showed spuriously high amounts of land cover change. Notable among these are Llanos of South America and Cape York peninsula of Australia. In Llanos climatic potential for vegetation is limited by seasonal flooding that ar- rests plant growth; this is not accounted for in potential LAI estimation. In Australia we found the extrapolated long-term climate to be wetter than existing conditions, leading to high potential LAI over Cape York peninsula.

\section{Global Land Cover Changes Expressed as Changes in After-noon Radiometric Temperature}

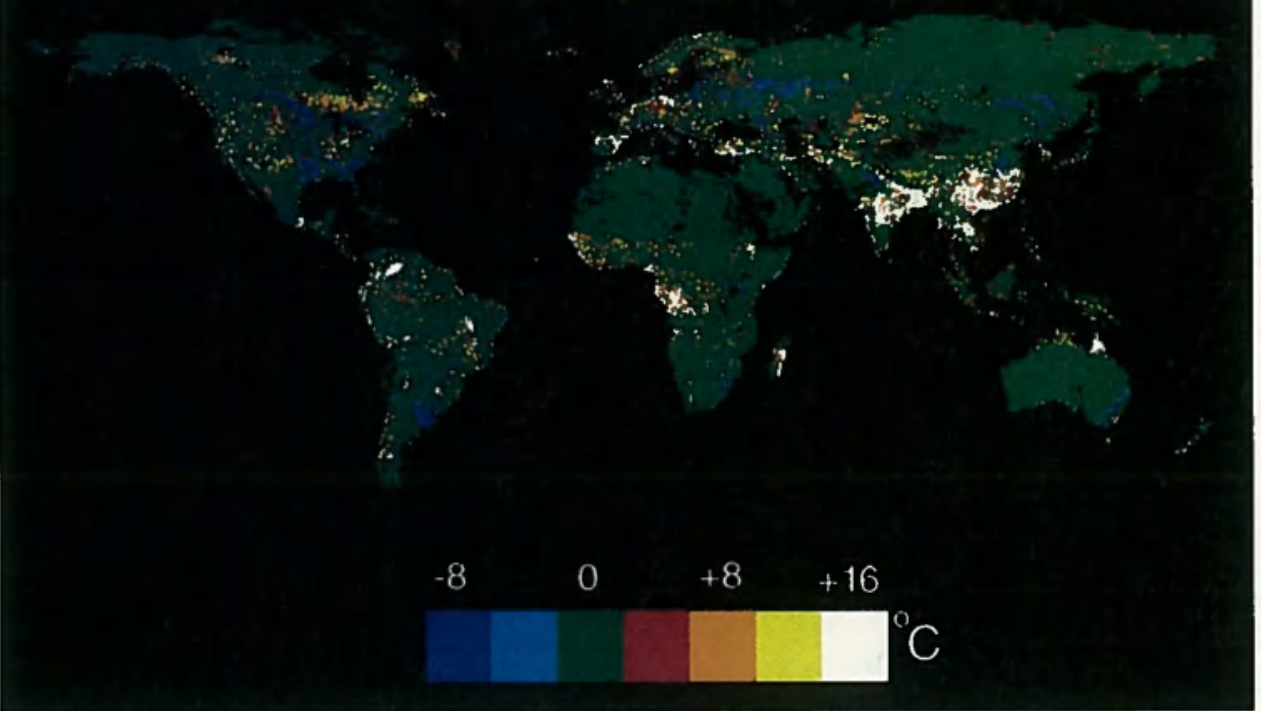

Plate 3. Changes in global land cover as a result of human activities, expressed as differences in afternoon 
changes in LAI, are only indicative of maximum possible changes under clear weather, midafternoon conditions, and should be interpreted with caution. Because of the poor coupling between $T_{\mathrm{r}}$ and $T_{\mathrm{s}}$, the actual changes in $T_{\mathrm{s}}$ would be much smaller in magnitude [Choudhury, 1991]. Accurate assessment of the impact of land cover changes can only be done with climate models using potential and actual vegetation parameters as inputs.

Phenological differences between forests and crops replacing forests with low canopy cover during springtime may also enhance the warming effect. Such a scenario is common over much of the temperate latitudes. These springtime changes in energy partitioning may be partly responsible for the consistent increase in global air temperatures during April and May [Swartz and Karl, 1990]. We are currently working on producing monthly LAIs for potential and actual conditions, which should improve seasonal land surface representation in GCMs.

Estimated land cover changes (Plate 3) seem to indicate that spatial heterogeneity in heat fluxes, the most important factor in altering local- to regional-scale circulation patterns, is likely to have increased from preagricultural times [Pielke and Avissar, 1990; Segal and Aritt, 1992]. Strong horizontal thermal contrasts exhibited in Plate 3 are found to be sufficient to trigger circulation patterns leading to severe thunderstorm activity that may not have occurred in preagricultural times [Anthes, 1984]. As a result, these mesoscale effects are now deemed necessary to be included in weather prediction and environmental assessment [Cotton and Pielke, 1994]. The predominantly local- to regional-scale changes in vegetation roughness, albedo, and wetness from irrigation, and thc corresponding changes in surface fluxes are not well represented in current coarse-resolution general circulation models (GCMs) [Li and Avissar, 1994]. Advanced GCMs with appropriate spatial resolution are needed to study the impact of land cover changes on global climate.

Finally, we would like to emphasize that land cover changes from our approach should be viewed only as gross features useful for global carbon and climatc modcls. Accuratc cstimation of LAI at $0.5^{\circ} \times 0.5^{\circ}$ resolution is not an easy task even with ground-based methods. While the techniques for computing potential and actual LAI are validated at stand level, their global application relies heavily on the quality of input data. In spite of the constraints with climate extrapolation, soils data, and spatial resolution associated with our potential LAI and actual LAI estimates, our analysis seems to provide a relatively accurate picture of land cover changes useful for global models. Significant improvements in the analysis can be made with better global data sets. For example, AVHRR data from the Pathfinder effort is better calibrated and comes at an 8-km resolution compared to the $16-\mathrm{km}$ GVI. The proposed algorithms for the Earth Observing System-era sensors such as the moderate-resolution imaging spectrometer (MODIS) would account for various problems that limit application of current AVHRR products [Running et al., 1994b]. Change detection is a highly scale-dependent process. While top-down approaches such as this study provide rough estimates, high-resolution studies along with cause-to-cover relations must be pursued [Skole and Tucker, 1993].

\section{Conclucions}

Changes in surface temperature resulting from land cover changes is an important aspect of climate change that needs to be better quantified. Land cover changes also produce several indirect effects on climatic processes through the release of $\mathrm{CO}_{2}$ from deforestation, biomass burning, trace gas emissions, land degradation leading to an increase in albedo, and changing hydrologic retention. Better monitoring of land cover changes and resulting biophysical responses is necessary to understand the true impacts of land cover changes on global environment and habitability.

Acknowledgments. This research was funded by Terrestrial Ecology and Earth Observing System programs of NASA. We acknowledge Ranga Myneni for his assistance in satellite LAI estimation, J.-P. Malingreau and Hugh Eva for providing AVHRR data over the Amazon, and C. D. Keeling for useful discussions.

\section{References}

Anthes, R. A., Enhancement of convective precipitation by mesoscale variations in vegetative covering in semiarid regions, J. Clim. Appl. Meteorol., 23, 540-553, 1984.

Asrar, G., E. T. Kanemasu, and M. Yoshida, Estimates of leaf area index from spectral reflectance of wheat under different cultural practices and solar angle, Remote Sens. Environ., 17, 1-11, 1985.

Asrar, G., R. B. Myneni, and B. J. Choudhury, Spatial heterogeneity in vegetation canopies and remote sensing of Absorbed Photosynthetically Active Radiation: A modeling study, Remote Sens. Environ., 41, 85-101, 1992.

Bonan, G., D. Pollard, and S. Thompson, Effects of boreal forest vegetation on climate, Nature, 359, 716-718, 1992.

Choudhury, B. J., Multispectral satellite data in the context of land surface heat balance, Rev. Geophys., 29(2), 217-236, 1991.

Cotton, W., and R. Pielke, Human Impacts on Weather and Climate, Cambridge University Press, New York, 1994.

Dickinson, R. E., and A. Henderson-Sellers, Modeling tropical deforestation: A study of GCM Land-Surface parameterization. $Q . J . R$. Meteorol. Soc., 114, 439-462, 1988.

Eagleson, P., Ecological optimality in water-limited natural soilvegetation systems. 1. Theory and hypothesis. Water Resour. Res.. 18. $325-340,1982$.

Flint, E. P., and J. F. Richards, Historical analysis of changes in land use and carbon stock of vegetation in South and Southeast Asia, Can. J. For. Res., 21, 91-110, 1991.

Gholz, H., Environmental limits on aboveground net primary production, leaf area and biomass in vegetation zones of the pacific northwest, Ecology, 63, 469-481, 1982.

Goward, S. N., G. D. Cruickshanks, and A. S. Hope, Observed relation between thermal emission and reflected spectral radiance of a complex vegetated landscape, Remote Sens. Environ., 18, 137-146, 1985.

Goward, S. N., D. G. Dye, S. Turner, and J. Yang, Objective assessment of the NOAA global vegetation index data product, Int. J. Remote Sens., 14, 3365-3394, 1993.

Green, G. M., and R. W. Sussman, Deforestation history of the eastern rain forests of Madagascar from satellite images, Science, 248, 212215,1990

Haack, B., N. Bryant, and S. Adams, An assessment of Landsat MSS and TM data for urban and near-urban land-cover digital classification, Remote Sens. Environ., 21, 201-203, 1987.

Houghton, R., The world-wide extent of land-use change, Bioscience, 44, 305-313, 1994.

Houghton, R. A., J. D. Unruh, and P. A. Lefebvre, Current land cover in the tropics and its potential for sequestering carbon, Global Biogeochem. Cycles, 7, 305-320, 1993.

Lean, J., and D. A. Warilow, Simulation of the regional climatic impact of Amazon deforestation, Nature, 342, 411-413, 1989.

Leemans, R., and W. Cramer, The IIISA climate data base for land areas on a grid with 0.5 degree resolution, WP-90-41, Int. Inst. for Apol. Sust. Anal. I axenbure. Austria 1900 . 
terminous U.S., Photogramm. Eng. Remote Sens., 57, 1453-1463, 1991.

$1593-1604,1992$.

Malingreau, J., and C. Tucker, Large scale deforestation in the southeastern amazon basin of Brazil, Ambio, 17, 49-55, 1988.

Myer, W. B., and B. Turner (Eds.), Global Land-Use:Land-Cover Change, Cambridge University Press, New York, 1994.

Nemani, R., and S. W. Running, Testing a theoretical Climate-SoilLeaf area hydrologic equilibrium of forests using satellite data and ecosystem simulation, Agric. For. Meteorol., 44, 245-260, 1989.

Nemani, R., L. L. Pierce, S. W. Running, and S. N. Goward, Developing satellite derived estimates of surface moisture status, J. Appl. Meteorol., 32, 548-557, 1993.

Nielson, R. P., A model for predicting continental scale vegetation distribution and water balance, Ecol. Appl., 5, 362-385, 1995.

Olson, J. S., J. A. Watts, and L. J. Allison, Carbon in live vegetation of major world ecosystems, TR004, U.S. Dept. of Energy, Washington, D.C., 1983.

Pielke, R. A., and R. Avissar, Influence of landscape structure on local and regional climate, Landscape Ecol., 4, 133-155, 1990.

Pierce, L. L., J. Walker, T. Dowling, T. Mcvicar, T. Hatton, S. Running, and J. Coughlan, Ecohydrological changes in Murray-Darling basin, III, A simulation of regional hydrological changes, J. Appl. Ecol., 30, 283-294, 1993.

Prentice, I. C., W. Cramer, S. P. Harrison, R. Leemans, R. A. Monserud, and A. M. Solomon, A global biome model based on plant physiology and dominance, soil properties and climate, J. Biogeogr., 19, 117-134, 1992.

Price, J. C., Land surface measurements from the split window channels of NOAA-7 AVHRR, J. Geophys. Res., 89, 7231-7237, 1984.

Running, S. W., and R. E. Hunt Jr., Generalization of a forest ecosystem process model, for other biomes, BIOME_BGC, and an application for global-scale models, in Scaling Processes Between Leaf and Landscape Levels, edited by J. R. Ehleringer and C. Field, Academic, San Diego, Calif., 1991.

Running, S. W., T. Loveland, and L. L. Pierce, A vegetation classification logic based on remote sensing for use in global biogeochemical models, Ambio, 23, 77-81, 1994a.

Running, S. W., et al., Terrestrial remote sensing science and algorithms planned for EOS/MODIS, Int. J. Remote Sens., 15, 35873620, 1994b.

Schwartz, M. D., and T. Karl, Spring phenology: Nature's experiment to detect the effect of "green up" on surface maximum temperatures, Mon. Weather Rev., 118, 883-890, 1990.

Segal, M., and R. Aritt, Nonclassical mesoscale circulations caused by

Sellers, P. J., S. Los, C. Tucker, C. Justice, D. Dazlich, G. Collatz, and D. Randall, A revised land surface parameterization (SiB2) for atmospheric GCMs, 2, The generation of global fields of terrestrial biophysical parameters from satellite data, Int. J. Remote Sens., 15, $3519-3546,1994$.

Shukla, J., C. Nobre, and P. Sellers, Amazon deforestation and climate change, Science, 247, 1322-1325, 1990.

Skole, D., and C. J. Tucker, Tropical deforestation and habitat fragmentation in the Amazon: Satellite data from 1978-1988, Science, 260, 1905-1910, 1993.

Smith, R. C. G., and B. J. Choudhury, On the correlation of indices of vegetation and surface temperature over southeastern Australia, Int. J. Remote Sens., 11, 2113-2120, 1990.

Spanner, M. A., L. L. Pierce, S. W. Running, and D. L. Peterson, The seasonality of AVHRR data of temperate coniferous forests: Relation to leaf area index, Remote Sens. Environ., 33, 97-112, 1990.

Specht, R. L., and A. Specht, Canopy structure in eucalyptus dominated communities in Australia along climatic gradients, Oecol. Plant., 10, 191-213, 1989.

Townshend, J. R. G., C. O. Justice, W. Li, C. Gurney, and J. McManus, Global Land cover classification by remote sensing: Present capabilities and future possibilities, Remote Sens. Environ., 35, 243-255, 1991.

Tucker, C. J., J. R. G. Townshend, and T. E. Goff, African landcover classification using satellite data, Science, 227, 369-375, 1985.

Turner, D. P., G. Koerper, H. Gucinski, and C. Peterson, Monitoring global change: Comparison of forest cover estimates using remote sensing and inventory approaches, Environ. Monit. Manage., 26, 295305, 1993.

Woodward, F. I., Climate and Plant Distribution, Cambridge University Press, New York, 1987.

Zobler, L., A World soil file for global climate modeling, NASA Tech. Memo., 87802, 1986.

T. N. Chase and R. A. Pielke, Department of Atmospheric Science, Colorado State University, Fort Collins, CO 80523.

R. R. Nemani and S. W. Running, School of Forestry, University of Montana, Montana Forest and Conservation Experiment Station, Missoula, MT 59812-1063. (e-mail: nemani(a)ntsg.umt.edu)

(Received January 7, 1995; revised May 3, 1995; accepted June 15, 1995.) 